\title{
Miranda
}

Revue pluridisciplinaire du monde anglophone /

Multidisciplinary peer-reviewed journal on the English-

speaking world

13 | 2016

Thomas Spence and his Legacy: Bicentennial

Perspectives

\section{Theatre and the Avant-garde Today : An Interview with Tobias Biancone, Director General of the International Theatre Institute (UNESCO).}

Interview with Tobias Biancone

Ling Jian-e

\section{OpenEdition}

Electronic version

URL: http://journals.openedition.org/miranda/9487

DOI: $10.4000 /$ miranda. 9487

ISSN: 2108-6559

\section{Publisher}

Université Toulouse - Jean Jaurès

\section{Electronic reference}

Ling Jian-e, "Theatre and the Avant-garde Today : An Interview with Tobias Biancone, Director General of the International Theatre Institute (UNESCO).", Miranda [Online], 13 | 2016, Online since 23

November 2016, connection on 16 February 2021. URL: http://journals.openedition.org/miranda/9487 ; DOI: https://doi.org/10.4000/miranda.9487

This text was automatically generated on 16 February 2021.

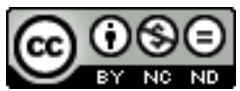

Miranda is licensed under a Creative Commons Attribution-NonCommercial-NoDerivatives 4.0 International License. 


\section{Theatre and the Avant-garde Today: An Interview with Tobias Biancone, Director General of the International Theatre Institute (UNESCO).}

Interview with Tobias Biancone

Ling Jian-e

\section{Websites}

1 ITI website : http://www.iti-worldwide.org/

[Figure 1]

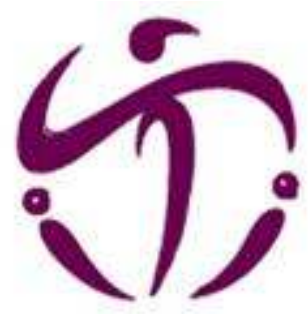

Logo ITI

ITI

PSi website : http://www.psi-web.org/

3 PSi20 website $:$ http://en.sta.edu.cn/content.aspx?id=292 


\section{Interview}

Ling Jian-e: It is a great pleasure to see you again here in Shanghai Theatre Academythanks to PSi20, Mr. Biancone. I guess that you don't remember when we met the first time.

Tobias Biancone: Actually I do remember. It was six years ago in Nanjing, when I was attending the $31^{\text {st }}$ Theatre of Nations of ITI.

LJE : Exactly! It was a feast for me, and first of its kind. The 10-day festival was an ecstatic Dionysian Festival. It was so exciting!

Tobias Biancone : And cold too, for October.

LJE : That I certainly don't remember. All I remember are those performances from all over the world! And you of course! I had no idea of what ITI represented back then. And I am not sure if ITI is well known to all our readers here in China [and elsewhere in the world, as a matter of fact], even though I have noticed China has been working closely with ITI in recent years. As Director General of this UNESCO affiliated organization, would you mind telling us how it came into being in the first place?

Tobias Biancone: Three personalities were responsible for creating ITI : J.B. Priestley, British playwright and novelist ; the first French culture minister and writer, André Malraux, and the first UNESCO Director General, Julian Huxley, an extraordinary scientist and humanist, brother of Aldous Huxley. Just after World War II UNESCO and these outstanding personalities wanted there to be an international organization that cares for the performing arts and the education in it and also uses the power of the theatre arts for mutual understanding and peace. The founding Centres in 1948 included not only France, Switzerland and the UK ...

LJE : And also China, as I learned from ITI website. It says there were 12 Centres when ITI was officially launched in Prague in 1948.

Tobias Biancone : Right. After that ITI served mainly to bridge the East and the West, over the Iron Curtain, and it did it very well. But after 1989 when the Soviet Empire broke down and the Iron Curtain fell, it went into a steep decline. The leaders at that time did not know how to keep ITI strong and alive. Since I entered the office in 2008, most of the work concerned in evolving and modernizing ITI. A difficult task. But together with the members of the Executive Council and the General Secretariat we are becoming an organization that serves the field of the performing arts in more and more countries. At the moment we are active in 100 countries, and the number of Centres is increasing.

LJE : Do you think that ITI has this incredible power of bringing people together, and make differences to our lives?

Tobias Biancone : Definitely. This very potential is based on the power of the theatre arts-and this includes all the performing arts, also dance and music theatre. The power is created by individual initiative by ITI members and affiliated organizations -channeled by the team of practitioners of ITI.

LJE : What has ITI to do with Theatre of Nations?

Tobias Biancone: Theatre of Nations-in French Théâtre des Nations-was created in Paris by the French. It was a leading and pioneer international festival. It brought for instance the first Chinese Opera of the People's Republic of China to the West, in the early fifties of the last century. Since 1972 the label has belonged to ITI and is no longer performed in Paris. It is traveling all over the world. In1997 the edition was 
held in Zurich/Switzerland and as mentioned 2008 in Nanjing/China. The next edition might be in Sharjah/United Arab Emirates and there is strong interest in China for further editions of the festival.

LJE: The Chinese Centre of ITI seems to be very much involved and committed in promoting the arts. There was an ITI World Congress in Xiamen, what was it about?

Tobias Biancone : ITI holds a World Congress every 2 to 3 years. The Xiamen Congress in September, 2011 was the $33^{\text {rd }}$ edition, and it was ITI's best congress ever. We had 350 delegates gathering for discussions and another 350 artists performing on that occasion. The organizers were very supportive, and the host showed a spectacular showcase of Chinese Opera and Theatre. The next edition is going to take place in Yerevan/Armenia from 17 to 22 November 2014.

LJE : Interesting... Let us talk about PSi 20 that brings you here now and let's start by the performances. What was your impression of Hamlet and Miss Julie in Beijing Opera style, and these foreign students in STA singing Beijing Opera in English in their experimental drama Queen Mab ?

Tobias Biancone: These are new forms of Beijing Opera. Chinese playwrights and directors are seeking inspirations from Western Theatre to further advance its development in this global age.

LJE : Would you say this is an avant-garde move?

Tobias Biancone: This is definitely an avant-garde move, and I hope that this is only the beginning of a new avant-garde and innovations in the chinese theatre arts. Theatre arts are live arts and they are played for an audience. I am sure if the Chinese performing artists are putting this communication between the people on stage with the audience into the centre of their work, avant-garde will evolve inevitably.

LJE: What inspired me to do this interview above all was your address at the opening ceremony of PSi20. Speaking to some 500 delegates from all over the world who gathered at STA to discuss and perform the conference theme of "avant-garde, tradition and community," you gave us this speech that was far more than ceremonial or ritualistic. In fact, I am tempted to say it is an avant-garde address on the avant-garde.

Tobias Biancone : That is your judgment.

LJE : One of the first things that really struck me is when you said that the avant-garde "was an anti-academy movement." What do you mean by that ? Is it a reference to what Marinetti advocated in his 1909 Futurist Manifesto : "To destroy academy of any kind" ?

Tobias Biancone: No, not at all. I certainly don't mean to drop the academy or university education. We need them to lay the foundation of certain skills. What I meant to say is that the term "avant-garde" sometimes indicates the artists, writers, theatre makers and composers would oppose the tradition taught at the academies.

LJE : But you also referred to STA as "an avant-garde institution for the Performing Arts and related studies."

Tobias Biancone : Yes, I did say that. But I have also said, "simple questions may have a multitude of answers." The question of what is the avant-garde is not even a simple question.

LJE : I agree. So many people have tried to theorize the avant-garde. From Renato Poggioli to Peter Burger in Europe, from Clement Greenberg toMatei Calinescu in America, the common ground of the avant-garde as they see it really remains very elusive. When you said that "history will tell" if any work is really avant-garde I thought of Eugene Ionesco's idea of the avant-garde right away. The avant-garde French playwright saw the avant-garde 
as "an artistic and cultural phenomenon of a precursory nature, which tallies with its literary meaning." Accordingly, he concludes that "the avant-garde cannot generally be recognized until after the event; when they have succeeded, when the avant-garde writers and artists have acquired a following, when they have founded a prevailing school, a cultural style which is recognized and will conquer an age."For me, this is a perfect footnote to your "history will tell."

Tobias Biancone: Yes, it explains what I mean. But one has to know that to be avantgarde is to be somewhat provocative as well. One has always to judge for himself and think for himself, and one should not be intimidated by established traditions. Gottfried Helnwein, an Austrian painter, who is known for his provocations, once told me this story: one day he was taking a taxi to bring his small painted portrait of Hitler that was a small part of an assembly of pictures. Helnwein-known for his portraits of John F. Kennedy and Mick Jagger on the covers of Time Magazine-knew that this would create a scandal. But he was somehow shocked himself when the taxi driver opened his glove compartment and took out a picture of Hitler-meaning that this man, after the atrocities of World War II still was an admirer of the dictator. This small event shows that avant-garde has to do with the community. And some action of an artist may unveil attitudes of the community he does not foresee.

LJE : So to be avant-garde is really to be creative at first.

Tobias Biancone : All art has to stem from an individual urge to create, avant-garde or traditional.

LJE : No wonder you devote a bigger part of your speech making connections between the avant-garde and the creative process, even though you are fully aware of the more common reception of the avant-garde as, in your own words, a term "used in the arts, literature, theatre and music for those who experiment, break borders and pave the way for future generations to follow."

Tobias Biancone: That's right. Doing the avant-garde is about breaking borders and paving the way for the future.

LJE : And it is what makes the avant-garde admirable : paving the way for others to follow. Right here you swiftly switch to challenge the institutions of higher education in the performing arts to create "a new avant-garde."

Tobias Biancone: Yes, that's what I hope to see, and I believe it can be done, and should be done.

LJE : Personally, I find your challenge a very compelling one. You were more demanding, on behalf of audiences worldwide regardless of their background. You wanted the institutions to present high quality performances for the general public, and not for a small circle of insiders. You said: "Does not everybody independently of his or her education, of his or her background, independently of age and gender and of his or her social status in the society have a right to watch an inspiring, interesting, high quality performance on stage ?" I silently applauded more than three times, silently, when you said that.

Tobias Biancone: Thank you. I do feel this public duty of the higher institutions has to be taken really seriously, not just those in the performing arts of course, but institutions in general.

LJE: Didn't you speak of the urgency of this not long ago in Beijing, at the opening ceremony of the $1^{\text {st }}$ World Theatre Education Convention?

Tobias Biancone : As a matter of fact, I did. 
LJE: Has ITI done anything else to meet the urgent need? This public duty of the institutions of higher learning?

Tobias Biancone: We have, indeed. We are pleased to have 21 universities that have joined the UNESCO/ITI Network of Higher Education Institution in the Performing Arts. There are universities from Europe, the Americas, Africa and Asia/Pacific

LJE : So you are hoping this network can get more young people away from Karaoke?

Tobias Biancone : Not at all. If I were young I would go to Karaoke. Definitely. But it is not a matter of "either or," but a matter of "and." I mentioned in my speech the performance has to reach audience of today, including "those young people who prefer to go to a Karaoke with their friends." I had my first Karaoke experience in Xiamen during the Congress we were talking about. I learned that Karaoke is extremely popular among Chinese young people. So I asked these students who had been helping at the Congress whether they had ever been to any theatre performances. More said no sadly, but one or two did say they began to like the theatre once they saw a real good performance.

LJE : You'd like to see more theatre enthusiasts than Karaoke enthusiasts. Wouldn't you?

Tobias Biancone: Nope. I'd like to see more young people loving theatre, and creative work in general. You see those who start loving theatre because the performances are so inspiring that they do not want to miss them.

...

TB : Sounds like avant-garde here, thinking for herself and judging for herself.

LJE : If you were to name a few avant-garde artists, who would they be please?

TB :The painters Felix Klee and Piet Mondrian were very avant-garde, so was WassilyKandinsky.

LJE : Klee, Mondrian and Kandinsky are real modern masters.

Tobias Biancone: Yes, they are. But one needs to know that not all modern artists are necessarily avant-garde.

LJE : I see. You are distinguishing the modern or modernist from the avant-garde, breaking away from the Anglo-American tradition which often uses both terms interchangeably.

Tobias Biancone: We can leave such theoretic inquiries to scholars. Let me remind you of one more important message in my speech, that is, art as communication. If I were to teach, I'd ask my students to write perhaps a poem on a blank paper, and see what they have to say. They may give me a good poem, a bad poem. In reading the poems, I would get to know them.

LJE : A poet as you are, you can't help talking about your own calling.

Tobias Biancone: Yes, but I have also seen spectacular theatrical performances as communication, powerful communication. In Brazil actresses and actors are performing everywhere, on the street, at the metro stations, etc. They engage the audience tremendously. Whoever passes by may be invited to join them. They raise consciousness. They advocate involvement.

LJE : Do you think theatre has a therapeutical power?

Tobias Biancone : Therapy is not the goal of the performing arts. It may happen but art for me has to do with inspiration, increasing awareness and consciousness. And art can create self-respect for the artists. Here is an example : There is a theatre group 
called Ramba Zamba. Some ten years ago, the team was invited to create a play with prisoners in Santiago de Chile. When they arrived at the prison they told the prisoners. If you look for a therapy, don't join this project. What our intention is, is to make you professional actors. And that is what they did with the prisoners. At the end they were performing the play in the prison. The performance was extremely well received by the other prisoners but also by the people from outside. One director of a community centre asked if the performance could be shown outside of the prison at his community centre. Well, that created a problem. The members of Ramba Zamba and the director were in doubt if that would work, to take those prisoners outside... They thought they would escape. And the prisoners were not "light" but "heavy" persons who were in prison because of rape, murder or arson. Finally they asked the prisoners what they thought. That is what they said. "We are in prison because we have done something wrong against society. We have to correct that by the means the society has provided for us. So do not fear that we will not come back. We will perform outside and come back." And that is what they did. Those prisoners have become actors with pride to be actors and with the competence. For me that shows the transformative power of the theatre arts. But it has to do with the restoration of self-respect and with creating competent actors.

LJE: I see. This really illustrates what you think the theatre arts can do and should do. Thanks a lot for the interview and good luck to you and ITI.

Tobias Biancone : Good luck to you too.

\section{NOTES}

1. A Chinese version of the interview was published in August, 2015 by Yihai (The Arts), a monthly journal issued by Hunan Provincial Art Research Institute, P.R.China. We would like to thank the editor in chief of Yihai who granted permission for the publication of the translation of the original interview.

\section{ABSTRACTS}

This interview with Tobias Biancone, Director General of the International Theatre Institute (ITI), was conducted on the afternoon of July 8, 2014 at Café \& Deli of Shanghai Theatre Academy (STA). Mr. Biancone was invited as keynote at the Performance Studies international Conference 20 (PSi20) : he addressed the theme of "Avant-garde, Tradition, Community," and talked about his vision of contemporary Chinese theatre. ${ }^{1}$ 
Entretien avec Tobias Biancone, Directeur Général du International Theatre Institute (ITI), réalisé le 8 juillet 2014 au Café \& Deli du Shanghai Theatre Academy (STA). Mr. Biancone était invité à donner une conférence plénière dans la cadre du colloque international Performance Studies international Conference 20 (Psi20) : il aborda le thème "Avant-garde, Tradition, Communauté », et évoqua sa vision du théâtre contemporain chinois.

\section{INDEX}

Subjects: Theater

Keywords: Tobias Biancone, the Avant-garde, avant-garde theatre, ITI, PSi20, contemporary Chinese theatre

Mots-clés: Tobias Biancone, l'Avant-garde, théâtre d'avant-garde, ITI, PSi20, théâtre contemporain chinois

\section{AUTHOR}

\section{LING JIAN-E}

Associate Professor/Maître de conférences

Hunan University of Science and Technology (Xiangtan, China)

lindalje@163.com 